\title{
Disturbance of inorganic phosphate metabolism in diabetes mellitus: temporary therapeutic intervention trials
}

This article was published in the following Dove Press journal:

Diabetes, Metabolic Syndrome and Obesity: Targets and Therapy

7 October 2009

Number of times this article has been viewed

\author{
Jørn Ditzel \\ Hans Henrik Lervang \\ Department of Endocrinology, \\ and Center for Prevention of Struma \\ and Metabolic Diseases, Aalborg \\ University Hospital, Aarhus University, \\ Denmark
}

\begin{abstract}
A paradoxical metabolic imbalance in inorganic phosphate occurs from the early onset of diabetes and may lead to a reduction of high energy phosphates and tissue hypoxia. These changes take place in the cells and tissues in which the entry of glucose is not controlled by insulin, and particularly in poorly regulated diabetes patients in whom long-term vascular complications are more likely to occur. Several therapeutic intervention trials have been carried out, including assessment of optimal glucose regulation, the effect of dietary inclusion of calcium diphosphate and pharmaceutical intake of etidronate disodium (EHDP), but none of these modalities wholly overcome the problem. The potential therapeutic application of fructose-1, 6-diphosphate, however, which also acts as human bioenergy, holds a great deal of promise as an efficacious and well-tolerated therapeutic regimen.
\end{abstract}

Keywords: diabetes, inorganic phosphate metabolism, early intervention trials

Diabetes mellitus is the most common human metabolic disorder, and a major health concern is the severe morbidity and mortality of the late diabetic complications. In our efforts to elucidate the mechanisms leading to the early functional changes in the retina and kidneys of diabetes patients, we noted repeated evidence of a disturbance in the metabolism of inorganic phosphate (Pi). ${ }^{1-6}$ Phylogenetic, experimental and clinical research data in nondiabetic conditions strongly suggests that the plasma and/or intracellular concentration of Pi may be a determining factor in regulation of energy metabolism and rate of oxygen consumption..$^{7-13}$ Diabetes mellitus, however, demonstrates the opposite behavior, in that the highest oxygen consumption is associated with the lowest content of inorganic phosphate, and lowering oxygen consumption is associated with higher concentration of inorganic phosphate. Since a reduction of high energy phosphates and tissue hypoxia may be important factors in the development of long-term diabetic complications (DLC), the effects of Pi on the metabolism and function of the erythrocyte and renal tubular cell, as well as local and systemic consequences of severe hypophosphatemia in and during recovery from diabetic ketoacidosis, have recently been reviewed (J Ditzel and HH Lervang, unpublished data). The results indicate, that most conventionally treated diabetic patients respond as if their tissues are in a state of chronic hypoxia and suggesting that erythropoietin (EPO) is stimulated at an early stage in diabetes. A major disturbance in phosphate handling occurs in the kidney tubules, where the excessive sodium-dependent glucose reabsorption in diabetics depolarizes the electrochemical sodium gradient.
Correspondence: Hans-Henrik Lervang Department of Endocrinology, Aalborg University Hospital, Aarhus University, 9000, Aalborg, Denmark

$\mathrm{Tel}+4599326125$

$\mathrm{Fax}+4599326008$

Email HHL@RN.DK 
Since Pi use the same driving force, but have less binding to sodium than glucose and amino acids such as alanine, the Pi reabsorption, particularly in poorly regulated patients, becomes impaired. This paradoxical phosphate imbalance may lead to affinity hypoxia and impaired formation of high energy phosphates. The lack of intracellular phosphate complementary to the increased intracellular glucose takes place in the insulin-insensitive cells and tissues, resulting in the possibility of DLC.

Many of the obvious dietary and pharmacological routes explored thus far to overcome this problem are evaluated herein.

\section{Effect of optimal blood glucose control}

Many investigators have found decreased concentrations of $\mathrm{Pi}$ in poorly regulated diabetic patients and slightly elevated levels when optimally controlled.

In newly diagnosed, nonacidotic insulin-dependent diabetic patient's plasma Pi concentration was normal at admission, showed lower range on the day after initial insulin administration and slightly above normal level on the day of best metabolic control. Red cell 2, 3-diphosphoglycerate (2, 3-DPG) exhibited the same fluctuating pattern, and Pi correlated closely to 2, 3-DPG ( $\mathrm{r}=0.61 ; P<0.001$ ). Red cell 2, 3-DPG concentration correlated equally well with $\mathrm{P}_{50}$ (oxygen tension at $50 \%$ oxygen saturation) of the oxyhemoglobin dissociation curve (ODC). ${ }^{14,15}$

Gertner et $\mathrm{al}^{16}$ studied mineral metabolism in 7 juvenileonset diabetic patients before and after achieving nearnormal glucose levels by 7 to 14 days treatment with a portable subcutaneous insulin infusion system. They found that as plasma glucose decreased from an average of $221 \mathrm{mg} / \mathrm{dL}$ to $95.9 \mathrm{mg} / \mathrm{dL}$, serum Pi rose from 4.09 to $5.01 \mathrm{mg} / \mathrm{dL}(P<0.001)$ due to a $25 \%$ rise in renal tubular threshold for phosphate. No change was noted in immunoreactive parathyroid hormone (PTH) and in 1, 25 hydroxy-vitamin D.

Ditzel et $\mathrm{al}^{4}$ studied renal handling of Pi in 26 conventionally treated diabetic children vs 28 healthy children and found fasting urinary phosphate excretion 3 times higher in the former group despite a significantly lower fasting Pi. The maximal capacity of renal tubular reabsorption of phosphate per liter of filtrate $\left(\mathrm{T}_{\mathrm{mPO} 4} / \mathrm{GFR}\right)$ was significantly suppressed in the diabetic patients. The increased urinary phosphate excretion correlated positively with both urinary glucose excretion and blood glucose concentration $(P<0.01)$. This finding was unrelated to serum PTH or to plasma growth hormone.
Raskin and Pak $^{17}$ studied 21 diabetic patients in whom treatment results ranged from "suboptimal" to "optimal" control and found that, as the mean plasma glucose decreased from $17.1 \mathrm{mmol} / \mathrm{L}$ to $5.2 \mathrm{mmol} / \mathrm{L}$ over 4 to 10 days, serum phosphate level rose from 1.12 to $1.26 \mathrm{mmol} / \mathrm{L}$ $(P<0.001)$.

The same significant increase in $\mathrm{Pi}$ was found in 28 patients with type 2 diabetes who were examined both at admission when their disease was poorly controlled and following several days of hospitalization and treatment had markedly improved their metabolic status. In these patients, serum Pi levels increased significantly from $1.12 \mathrm{mmol} / \mathrm{L}$ to $1.21 \mathrm{mmol} / \mathrm{L}(P<0.01)$, while serum calcium remained unchanged and urinary calcium and phosphorous excretion both decreased. On admission urinary calcium and phosphorous excretions showed a positive correlation with glucose excretion. Serum PTH decreased from a mid-normal to a low-normal value. ${ }^{18}$

Thus, in both type 1 and type 2 diabetes, there is a close correlation between the Pi concentration in plasma and an improvement in diabetes control and in intracellular phosphate with a stimulating influence on the rate of cell glycolysis.

\section{Effect of dietary phosphate intake}

Pi concentration may also be increased by increasing dietary phosphate. Adding $2 \mathrm{~g}$ of calcium diphosphate to the three main daily meals over 4 weeks resulted in increased mean content of intraerythrocytic-2, 3-DPG and in the $\mathrm{P}_{50}$ of the ODC in both juvenile and adult diabetes patients. ${ }^{19}$ To determine whether the immediate effect of increased phosphate intake persisted a subsequent double-masked, placebo-controlled study was undertaken for 1 year to assess renal processing of phosphate and bone mineral content in 43 juvenile type 1 diabetic patients. No increase was seen in the concentration of $\mathrm{Pi}$ (active $\mathrm{n}=19: 1.33 \mathrm{mmol} / \mathrm{L}$ vs placebo; $\mathrm{n}=24: 1.42 \mathrm{mmol} / \mathrm{L}$, $P=$ ns). ${ }^{20}$ In the treatment group, the fasting urinary phosphate excretion increased as compared to the placebo group (median 1.28 vs $1.01 \mathrm{mmol} / \mathrm{h} ; P<0.001$ ) and phosphate clearance/GFR was significantly enhanced ( 0.16 vs 0.10 ; $P<0.001)$. The threshold concentration of phosphate $\left(\mathrm{T}_{\mathrm{m}} \mathrm{PO}_{4} / \mathrm{GFR}\right)$ was suppressed (1.19 vs $1.42 \mathrm{mmol} / \mathrm{L}$; $P<0.01)$ in the treatment vs placebo group, and in contrast to the controls (1.81 vs $1.42 \mathrm{mmol} / \mathrm{L} ; P<0.001)$ (Figure 1 ). The threshold concentration $\mathrm{T}_{\mathrm{m}} \mathrm{PO}_{4} / \mathrm{GFR}$ was not related to the level of parathyroid hormone or to growth hormone level in serum, but inversely correlated with the degree of hyperglycemia. No difference in bone mineral content 


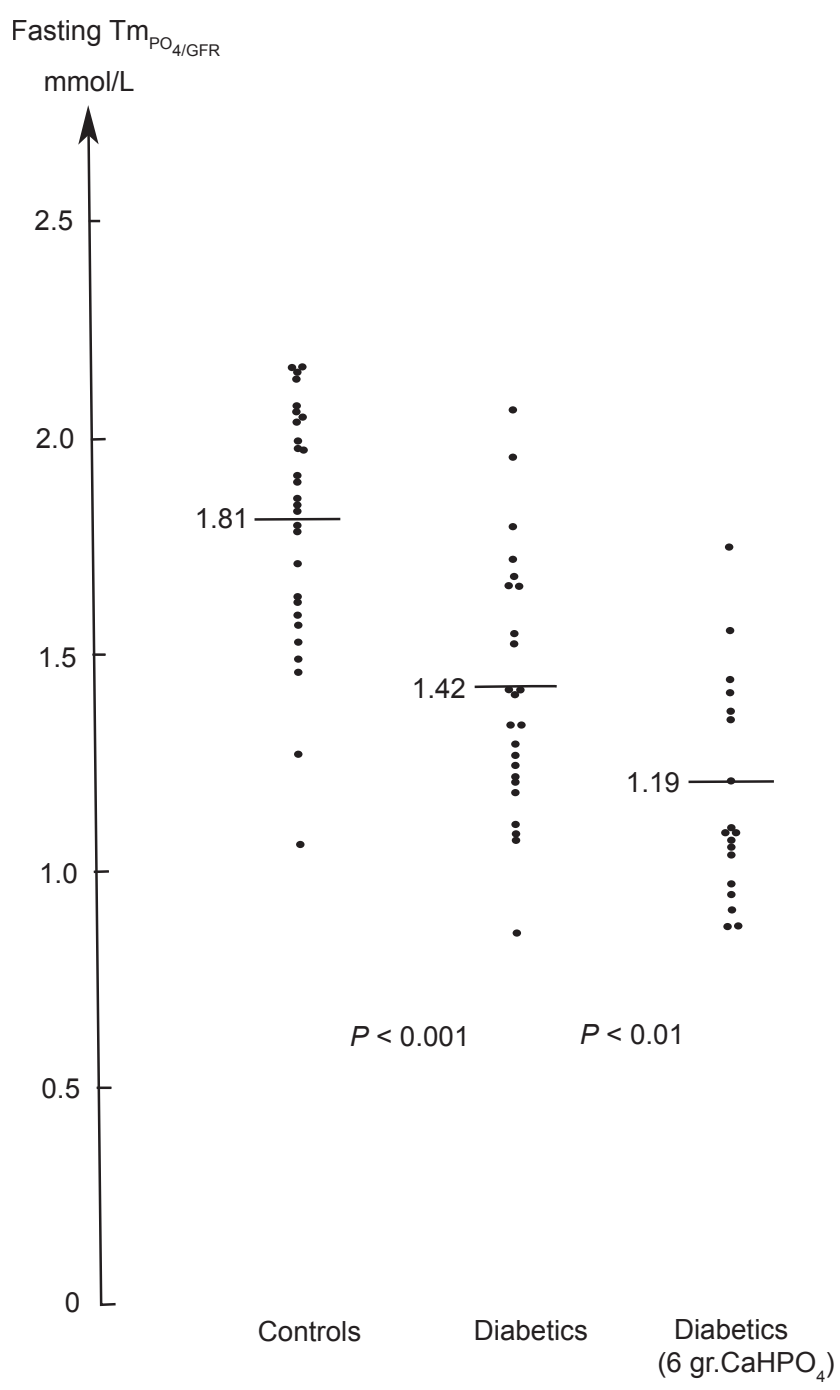

Figure I The phosphate threshold concentration, which is numerically equal to maximum tubular reabsorption rate for phosphate per unit volume of glomerular filtrate in 28 healthy children $(1.8 \mathrm{Immol} / \mathrm{L})$ vs 24 conventionally treated diabetic children without microvascular complications ( $1.42 \mathrm{mmol} / \mathrm{L})$ and 19 diabetic children whom received 6 grams of calcium diphosphate daily for one year $(1.19 \mathrm{mmol} / \mathrm{L})$.

was found between the treatment and placebo groups. These observations demonstrate that the dysfunction of the tubular handling of phosphate in diabetic children associated with hyperglycemia cannot be compensated for by daily dietary supplements of calcium diphosphate.

\section{Effect of etidronate disodium (EHDP)}

Intake of the diphosphonate, ethane-1, 1-diphosphonate (EHDP) is known to produce sustained hyperphosphatemia. ${ }^{21-23}$ This rise in Pi concentration occurs without a corresponding increase in urinary phosphate excretion, suggesting that EHDP partly elevates Pi by reducing its renal clearance. To study the effect of prolonged elevation of Pi on red cell metabolism and function, oxyhemoglobin dissociation curves (ODC) from zero to full saturation were performed on whole blood from 14 insulin-treated, nonacidotic diabetes patients and 5 healthy volunteers following oral intake of EHDP $\left(20 \mathrm{mg} \mathrm{kg}^{-1} \mathrm{day}^{-1}\right)$ or placebo for 28 days. ${ }^{24}$ The mean Pi increased from 1.18 to $1.57 \mathrm{mmol} / \mathrm{L}(P<0.001)$ in the diabetes patients and from 1.14 to $1.69 \mathrm{mmol} / \mathrm{L}(P<0.005)$ in healthy controls. A significant rise in red cell 2, 3-DPG was seen only in the diabetic group from 15.2 to $16.3 \mu \mathrm{mol} / \mathrm{g}$ of hemoglobin $(P<0.005)$ and probably indicates a suppression of the 2, 3-DPG formation pathway in diabetes patients. However, there was a significant relationship between the concentration of $\mathrm{Pi}$ and the $\mathrm{P}_{50}$ of the ODC in both diabetics $(\mathrm{r}=0.58$, $P<0.01)$ and healthy controls $(\mathrm{r}=0.69, P<0.005)$. Mean $\mathrm{P}_{50}$ in diabetic patients was significantly lower than controls despite normal 2, 3-DPG. The study emphasizes the importance of Pi on red cell function and indicates that elevated Pi tends to counteract the defect in oxygen-release capacity of the erythrocytes in diabetes patients. A subsequent randomized, 6-month, double-blind study of 26 type 1 diabetic patients with nonproliferative retinopathy confirmed the effect of EHDP on Pi, red cell 2, 3 -DPG and $\mathrm{P}_{50}$ of ODC. ${ }^{25}$ Furthermore, the lack of changes in mean glucose and $\mathrm{HbA}_{1 \mathrm{c}}$ indicated an interesting association between improvement in retinopathy as evaluated by retinal fluorescein angiography and increased $\operatorname{Pi}(P<0.05)$.

\section{Potential therapeutic application of fructose-I , 6-diphosphate}

Fructose-1, 6-diphosphate (FDP) is a key intermediate in anaerobic glycolysis and is the product of the major regulatory enzyme in the pathway (phosphofructokinase). Natelson et $\mathrm{a}^{26}$ showed that orally administrated fructose diphosphate calcium salt was absorbed directly by the intestinal tract without splitting the phosphate linkage, and that $6 \mathrm{~g}$ led to an increase of serum inorganic phosphate averaging $15 \%$, citric acid $10.7 \%$, and nonprotein organic phosphate as much as $173 \%$. Further preclinical and clinical data indicate that FDP can enter cells and serve as a metabolizable substrate of glycolysis. ${ }^{27-29}$ FDP acts as human bioenergy and can transport phosphorous intracellularly as well as deliver 4 moles of ATP per mole of FDP. Thus FDP has substantial cytoprotective effects on a variety of ischemia-induced tissue damage. ${ }^{30,31}$ Recent studies also show that FDP can modulate nitric oxide production in a variety of cellular injury events, and indicate that FDP can influence red cell rheology and can increase red cell ATP and 2, 3-DPG levels. ${ }^{32-34}$ FDP can be given orally and intravenously to humans and it is well 
tolerated at pharmacological doses. Although FDP appears to be highly efficacious, no previous controlled study has been reported in diabetic patients.

\section{Discussion}

This review demonstrates a close correlation between plasma concentration of $\mathrm{Pi}$ and the degree of metabolic control of diabetes. The relationship may involve $\mathrm{Pi}$ handling in the kidney tubules; the major regulator of $\mathrm{Pi}$ homeostasis. Glucose and Pi (eg, alanine, myoinositol) reabsorption are all examples of secondary active transport processes with sodium $\left(\mathrm{Na}^{+}\right)$as the driving force. The sodium entry results from the active extrusion of $\mathrm{Na}^{+}$ across the basolateral segment of the proximal tubular cells, energized by adenosine triphosphate (ATP) hydrolysis, and catalyzed by the $\mathrm{Na} / \mathrm{K}$-ATPase. As glucose is more potent than inorganic phosphate in stimulating the uptake of $\mathrm{Na}^{+}$ in renal microvillus vesicles, ${ }^{35}$ the elevated glucose concentrations depolarize the transmembrane electrochemical $\mathrm{Na}^{+}$gradient of the brush border membrane for inorganic phosphate entry into the tubular cells and decrease intracellular phosphate leading to hyperphosphaturia. Therefore normalization of blood glucose levels leads to an improved capacity of the kidney tubules to reabsorb Pi and a subsequent increase in plasma Pi concentration. Over time this improved glucose regulation will positively influence or even prevent the long-term diabetic complications as has been proven in DCCT and UKPDS studies. ${ }^{36,37}$ Although effective, however, this method achieves only an approximation of normalcy given the chronic and fluctuating nature of diabetes and the nonphysiologic administration of daily injections vs immediate insulin secretion into the portal circulation in response to a rise in blood glucose in healthy organisms.

Increasing the dietary intake of Pi with $6 \mathrm{~g}$ of calcium diphosphate has been shown to be of no benefit since the maximal reabsorptive capacity for Pi in the kidney tubules does not increase, but actually decreases leading to a significant increase in Pi clearance (Figure 1). ${ }^{20}$ This effect was not found to be related to the serum level of parathyroid hormone or growth hormone, but inversely correlated with the degree of hyperglycemia.

The study of the effect of etidronate disodium (EHDP) superficially appears to be more promising since EHDP increased both plasma Pi and red cell 2, 3-diphophoglycerate levels and thereby the oxygen release capacity. Studies of nonproliferative retinopathy suggested that a 6-month course of EHDP administration may improve retinopathy. ${ }^{25}$
EHDP in large doses may also suppress bone turnover, inhibits bone mineralization and affect tooth development, deleterious effects that discourage general use. ${ }^{38,39}$

The therapeutic use of fructose-1, 6 diphosphate (FDP) in diabetes is much more attractive since it is a natural intermediate in glycolysis and also acts as human bioenergy, delivering intracellular phosphorus and 4 moles ATP per mole of FDP. The substance is well tolerated at pharmacological doses and can be given orally. Future controlled studies may lead to a prophylactic therapy to prevent vascular complications and may also counteract the metabolic disturbances leading to type 2 diabetes and the metabolic syndrome. ${ }^{40}$

\section{Disclosures}

The authors declare no conflicts of interest.

\section{References}

1. Ditzel J. Effect of plasma inorganic phosphate on tissue oxygenation during recovery from diabetic ketoacidosis. Adv Exp Med Biol. 1973;37A: 163-172.

2. Ditzel J, Standl E. The problem of tissue oxygenation in diabetes mellitus. II Evidence of disordered oxygen release from the erythrocytes of diabetics in various conditions of metabolic control. Acta Med Scand. 1975;Suppl 578:S59-S68.

3. Ditzel J, Brøchner-Mortensen J, Rødbro P. Elevated glomerular filtration rate in early diabetes may be explained by increased sodium reabsorption secundary to impairment in renal tubular handling of phosphate. Hormone Metab Res. 1981;Suppl 11:S87-S89.

4. Ditzel J, Brøchner-Mortensen J, Kawahara R. Dysfunction of tubular phosphate reabsorption related to glomerular filtration and blood glucose control in diabetic children. Diabetologia. 1982;23(5): 406-410.

5. Ditzel J, Brøchner-Mortensen J. Tubular reabsorption rates as related to elevated glomerular filtration in diabetic children. Diabetes. 1983; 32 Suppl 2:S28-S32.

6. Mathiassen B, Nielsen S, Johansen JS, et al. Long-term bone loss in insulin-dependent diabetic patients with microvascular complications. J Diabet Complications. 1990;4(4):145-149.

7. Hardy HA, Wellman M. Oxidative phosphorylation. Role of inorganic phosphate and acceptor systems in control of metabolic rates. J Biol Chem. 1952;185:215-224.

8. Sestoft L. Regulation of fructose metabolism in the perfused rat liver. Interrelation with inorganic phosphate, glucose, ketone body and ethanol metabolism. Biochem Biophys Acta. 1974;343(1):1-16.

9. Brazy PC, Mandel IJ. Does availability of inorganic phosphate regulate cellular oxidative metabolism? News Physiol Sci. 1986;1:100-103.

10. Bose S, French S, Evans FJ, Balaban RS. Metabolic network control of oxidative phosphorylation: Multiple roles of inorganic phosphate. J Biol Chem. 2003;278(40):39155-39165.

11. Sestoft $\mathrm{L}$. Is the relationship between plasma concentration of inorganic phosphate and the rate of oxygen consumption of significance in regulating energy metabolism in mammals? Scand J Clin Invest. 1979;39(3):191-197.

12. Firmat G, Prunier J, Rawson RW, Roberts KE, Schwartz MK. Effect of phosphate enhancing the action of triiodothyronine. Endocrinology. 1956;59(5):565-570.

13. Mosekilde L, Christensen MS. Decreased parathyroid function in hyperthyroidism: interrelationshipp between parathyroid hormone, calcium-phosporous metabolism and thyroid function. Acta Endocrinol (Copenh). 1977;84(3):566-575. 
14. Ditzel J, Standl E. Plasma Pi and erythrocyte 2, 3DPG concentrations of non-acidotic diabetics in various degree of metabolic control. Clin Chem. 1976;22(4):550-551.

15. Ditzel J, Jæger P, Standl E. An adverse effect of insulin on the oxygen-release capacity of red blood cells in nonacidotic diabetics. Metabolism. 1978;27(8):927-934.

16. Gertner JM, Tamborlane WV, Horst RL, Sherwin RS, Felig P, Genel M. Mineral metabolism in diabetes mellitus. Changes accompanying treatment with portable subcutaneous insulin infusion. J Clin Endocrinol Metab. 1980;50(5):862-866.

17. Raskin P, Pak CYC. The effect of chronic insulin therapy on phosphate metabolism in diabetes mellitus. Diabetologia. 1981;21(1):50-53.

18. Nagasaka S, Murakami T, Uchikawa T, Ishikawa SE, Sato T. Effect of glycemic control on calcium and phosphorous handling and parathyroid level in patients with non-insulin-depemdemt diabetes mellitus. Endocr J. 1995;42(3):377-383.

19. Ditzel J. The problem of tissue oxygenation in diabetes mellitus III. Acta Med Scand. 1975;Suppl 578:S69-S83.

20. Ditzel J, Lervang HH, Brøchner-Mortensen J, Rødbro P. The influence of a dietary supplement of calcium and phosphate on bone mineral content and mineral homeostasis of diabetic children. Diabetologia. 1993;Suppl 1:A58.

21. Altman RD, Johnson CC, Khairi MRA, Wellman M, Serafini AN, Sankey RR. Influence of disodium etidronate (EHDP $\left.{ }^{\mathrm{TM}}\right)$ on clinical and laboratory manifestastion of Paget's disease of bone (osteitis deformans). N Engl J Med. 1973;289(26):1379-1384.

22. Recker RR, Hassing GS, Lau JR, Saville PD. The hyperphosphatemic effect of disodium-1-hydroxy-1, 1 diphophonate (EHDP ${ }^{\mathrm{TM}}$ ): Renal handling of phosphorus and the renal response to parathyroid hormone. J Lab Clin Med. 1973;81(2):258-266.

23. Russell RGG, Smith R, Preston C, Walton RJ, Woods CG. Diphosphonates in Paget's disease. Lancet. 1974;1(7863):894-898.

24. Ditzel J, Hau C, Daugaard N. Effect of diphosphonate ethane-1-hydroxy-1, 1-diphosphonate (EHDP) on hemoglobin oxygen affinity of diabetic and healthy subjects. Microvasc Res. 1977;13(4):355-361.

25. Nielsen NV, Ditzel J, Jensen S, Kjærgaard JJ. The effect of etidronate disodium (EHDP) on retinopathy in insulin-dependent diabetic patients. Graefe's Arch Clin Exp Ophthalmol. 1982;219(2):60-63.

26. Natelson S, Klein M, Kramer B. The effect of oral administration of calcium fructose diphosphate on the serum organic phosphate, inorganic phosphate, calcium protein, and citric acid levels. J Clin Invest. 1951(1);30:50-54.

27. Hardin C, Lazzarino G, Tavazzi B, Di Pierro D, Roberts TM, Giardino B, et al. Myocardial metabolism of exogenous FDP is consistent with transport by a dicarboxylate transporter. Am J Physiol. 2001;281(6):H2654-H2660.
28. Markow AK, Neely WA, Didioki RH, TerryIII J, Causey A, Lehan PH. Metabolic responses of Fructose-1, 6-diphosphate in healthy subjects. Metabolism. 2000;49(6):698-703.

29. Ehringer WD, Niu W, Chiang B, Wang OL, Gordon L, Chien S. Membrane permeability of fructose.1, 6.diphosphate in lipid vesicles and endothelial cells. Mol Cell Biochem. 2000;210(1-2):35-45.

30. Takeuchi K, Cao-Danh H, Frichs I, Glynn P, DÀgostino D, Simplaceanu E, et al. Administration of fructose 1,6-diphosphate during early reperfusion significantly improves recovery of contractile function in the postischemic heart. J Thorac Cardiovasc Surg. 1998;116(2): 335-339.

31. Antunes N, Martinusso CA, Takiya CM, de Silva AJR, de Omellas JFR Elias PR, et al. Fructose-1, 6 diphosphate as a protective agent for experimental ischemic acute renal failure. Kidney Int. 2006;69(1): 68-72.

32. Rao MR, Olinde KD, Markov AK. In vitro induction of nitric oxide by fructose-1, 6-diphosphate in the cardiovascular system of rats. $\mathrm{Mol}$ Cell Biochem. 1998;185(1-2):171-175.

33. Cacioli D, Clivate A, Pelosi P, Megevand J, Galeone M. Haemorheological effects of fructose-1, 6-diphosphate in patients with lower extremity ischemia. Curr Med Res Opin. 1988;10(10):668-674.

34. Urso L, Brillante C, Orlandi M, Rotundo M, Ballati S. Evaluation of fructose-1, 6-diphosphate on erythrocyte 2, 3 diphosphoglycerate and ATP in surgical orthopedic patients. Aggressologie. 1982;23(3):115-117.

35. Barrett PQ, Aronson PS. Glucose and alanine inhibition of phosphate transport in renal microvillus membrane vesicles. Am J Physiol. 1982;242(2):F126-F131.

36. The Diabetes Control and Complication Trial Research Group. The effect of intensive treatment of diabetes in insulin-dependent diabetes mellitus. N Engl J Med. 1993;329(14):977-986.

37. UK Prospective Diabetes Study (UKPDS) Group. Intensive blood glucose control with sulfonylureas or insulin compared with conventional treatment and risk of complications in patients with type 2 diabetes. (UKPDS 33). Lancet. 1998;352(9131):837-853.

38. Christoffersen J, Christoffersen NR, Ruben J, Arenda J. The effect of EHDP concentration on enamel demineralization in vitro. J Dent Res. 1991;70(2):123-126.

39. Hirano T, Turner CH, Forwood HR, Johnson CC, Burr DR. Does suppression bone turnover impair mechanical properties by allowing microdamage accumulation? Bone. 2000;27(1):13-20.

40. Håglin L, Lindblad A, Bygren LO. Hypophosphataemia in the metabolic syndrome. Gender differences in body weight and blood glucose. Eur J Clin Nutr. 2001;55(6):493-498.

Diabetes, Metabolic Syndrome and Obesity: Targets and Therapy

Dovepress

\section{Publish your work in this journal}

Diabetes, Metabolic Syndrome and Obesity: Targets and Therapy is an international, peer-reviewed open-access journal committed to the rapid publication of the latest laboratory and clinical findings in the fields of diabetes, metabolic syndrome and obesity research. Original research, review, case reports, hypothesis formation, expert opinion and commentaries are all considered for publication. The manuscript management system is completely online and includes a very quick and fair peer-review system, which is all easy to use. Visit http://www.dovepress.com/testimonials.php to read real quotes from published authors. 